\title{
Cultivation of "Cultural Confidence" in Foreign Literature Course from a Comparative Perspective
}

\author{
Lu Jie \\ The College of Foreign Languages, Chengdu University of Information Technology, China
}

Copyright $\odot 2019$ by authors, all rights reserved. Authors agree that this article remains permanently open access under the terms of the Creative Commons Attribution License 4.0 International License

\begin{abstract}
In the process of realizing "Chinese dream", cultural confidence is a key factor in encouraging Chinese students to make contributions to the construction of their motherland. As compulsory courses for English majors in China, English and American Literature courses are usually regarded as a window for Chinese students to know the western civilization, but in the new era of building the Socialism with Chinese Characteristics, cultivation of Chinese students' confidence of their own culture becomes equally important as cross-cultural competence does. This paper explores some possibilities from a comparative perspective to cater to the need of cultivation of cultural confidence in foreign literature course.
\end{abstract}

Keywords English and American Literature Courses, Comparative Perspective, Cultural Confidence

\section{Introduction}

Traditionally, the aims of English and American literature courses in Chinese Higher education are to cultivate students' ability to read, understand and appreciate English and American literary works and to master the basic knowledge and methods of literary criticism. Through reading and analyzing these literary works, students' basic language skills, cross-cultural competence and other related qualities can be improved. It can be seen that the purposes of English and American Literature Courses in Chinese colleges are to improve language skills through reading some native English and American writings, to enhance college students' quality by using English and American literature as materials of "liberal education", and to understand western civilization through the window of English and American literature. After the establishment and execution of the reform and opening-up policy, Chinese government advocated Chinese writers and artists to learn from their foreign counterparts, especially those from Britain and the United States. English and American literature became very popular among Chinese college students, even among those non-English majors. English and American literature teaching has enjoyed a prosperous period in China in the past 30 years. However, only depending on introduction and imitation of western culture cannot really realize "Chinese dream", because "Chinese dream" encompasses the goals of building a moderately prosperous society and realizing national rejuvenation, which means China tries to achieve prosperity, democracy, strength, unity, peace and harmony but not at the cost of losing its own cultural identity. Therefore, cultivation of cultural confidence becomes a must for Chinese students, and some new contents, goals and methods should be added to the traditional English and American Literature Courses in Chinese higher education institutions.

\section{Incorporating Chinese Literary Texts into English and American Literature Courses}

In the past two decades, Damrosh, Theo D'haen, Djelal Kadir, Sarah N. Lawall, John David Pizer and Totosy de Zepetnek Mukherjee have developed many new understandings about "world literature". World literature refers not only to the national literary classics that have gained world reputation, but also to the study of national literature from the perspective of cosmopolitanism. In particular, D. Damrosch holds that "World Literature" should include the category of literary production that gains in translation that may inspire new genres, enrich a local tongue's vocabulary, blend with regional concepts, or take on new meanings in new times and places. From his point of view, after Goethe's novel Sorrows of Young Werther was translated into Japanese, it influenced the budding "confessional novel" genre in late 19th century Japan, so undoubtedly the novel's Japanese version should be part of Japanese literature. Similarly, if a 
Chinese literary work greatly influences English or American literature, it should also be accepted as part of English or American literature. Therefore, the traditional teaching of English and American literature should conform to the trend of international literary research, not be mechanically based on the territory of British and American literature, but should be based on the new concept about "world literature". In addition to teaching and disseminating the original literary masterpieces by native British and American writers, some excellent translated Chinese literary works should also be included in English and American Literature Courses. For example, when lecturing Shakespeare's plays, some Chinese playwrights, such as Tang Xianzu (汤显祖), Guan Hanqin (关汉卿) and Cao Yu's (曹禺) masterpieces can be used for comparison; when analyzing Ezra Pound's poems, some verses by Li Bai (李白), Han Shan（寒山） and Ma Zhiyuan (马致远) can be used to illustrate the imagist features of juxtaposition and superposition of images; when discussing William Wordsworth's romantic poems, some Chinese classical scenery poems by Xie Lingyun (谢灵运)and Wangwei (王维) can be used to show their common interest in rustic and natural things; when analyzing Adeline Virginia Woolf's feminist writings, Chinese feminist writers Xue Tao(薛涛) and Yu Xuanji

（鱼玄机） can be introduced as her foreign forerunners.

Professor Xie Tianzhen (谢天振), the founder of medio-translatology in China, advocates that affiliation of translated literature should be decided by its target language instead of its original language, because in the field of art, translation is of re-creative nature and translation is an independent form of literary works and the translator is the author of the translated works. In an article written in 1989, he put forward that academically distinguishing translated literature from foreign literature is a revolution of traditional concept, and incorporating translated literature into national literature is an even more pioneering work. [1] In his new monograph The New Horizon of Translation Study, he puts forward: "The twentieth century is an epoch of translation, and it is over now; the twenty first century is an epoch of communication, and the communication in this new century is far more frequent than before. Maybe it is high time that the position of translated literature should be properly evaluated and recognized.”[2] Although Xie Tianzhen's attribution of translated literature has aroused some doubts from his predecessors in the field of translation study in China, his new understanding of the attribution of translated literature in the field of comparative literature research is similar to that of comparative literature variation proposed by Professor Cao Shunqing (曹顺庆). Cao puts forward that literature will inevitably experience variation when it is disseminated from one country to others. Language variation, translator's "creative treason", "cultural filtering" and "foreignization" caused by cultural differences are just some obvious phenomena of variations. Therefore, from the perspective of Comparative Literary variation, The Story of the Stone translated by David Hawkes, a British scholar, should of courses be an integral part of English literature as well as Shakespeare's great works. Yang Qing (杨青)and Geng Yanhong (耿延宏) propose that on the basis of Cultranslation and modern Reception Aesthetics, a translated version has its own aesthetics value because of a translator's creativity in understanding and reconstructing of the original text during the literary translation, so "the translated literature should be regarded as a special part of the national polysystem and a translator as an important participant in the construction of a notational culture”.[3] Thomas Oliver Beebee, editor-in-chief of Comparative Literature Studies, also supports Xie' and Cao's proposal. In an interview, he answered the interviewer's question about his attitude toward the affiliation of translated works. He said: "I agree with Professor Xie. This question is a question about multiple systems. Since translation literature has more influence on its target text, it is a better choice to classify translation literature as the target language."[4] Although the affiliation of translated literature is still in dispute, teachers of English and American literature welcome to embrace translated Chinese literature in their class.

At present, the textbooks of English and American literature in China are still based on their national literature, which introduces the important writers and works of the two countries. In such a teaching perspective and the contents of textbook, it is difficult for Chinese teachers to discuss Chinese literature in their class. The previous teaching contents' exclusion of Chinese literature deprived English and American Literature courses of their potential to cultivate Chinese students' cultural confidence. Now, Chinese government advocated a kind of implicit ideological and political education, so more and more teachers are trying to combine the traditional teaching of English and American literature with excellent Chinese literature. However, when Chinese teachers add translated Chinese literature into the original English and American Literature teaching, they should be well aware of the fact that in the new international trend of "world literature", both British and American literature and Chinese literature are absolutely not the "two poles" in the literary world. Neither "Western Centralism" nor "Oriental Centralism" is correct attitude to treat human literature. Only by integrating translated Chinese literature with the Western canons and breaking the inherent barriers between them can the academic dream of "harmony in diversity" come true. Therefore, only by incorporating the translated Chinese literature into the category of Anglo-American literature; in other words, only by establishing the legitimate status of the translated Chinese literature in the teaching of Anglo-American literature can 
teachers in Chinese Colleges and universities be able to cultivate students' confidence of Chinese literature. Generally speaking, the teaching of English and American literature in the new period needs to integrate Chinese and Anglo-American literature and confirm the legitimate position of translated Chinese literature in English and American literature curriculum.

\section{Bridging the Literary Gap with Comparative Methods}

After establishing the validity of the translation of Chinese literature in the teaching of English and American literature for English majors in Chinese higher schools, some "win-win" paths should be explored. English and American literature, as core courses for Chinese English majors, first of all should satisfy students' expectations of language skills, cultural knowledge and liberal education; however, for the rejuvenation of China, it should create a free atmosphere for teachers and students to carry out a comparative study between Chinese and Anglo-American literature.

In the history of Chinese and foreign literature exchanges, examples of comparison between Chinese and Western literature are very common. For example, when Premier Zhou Enlai (周恩来) attended the Geneva International Conference in 1954, he brought the Yue opera film “Liang Shanbo and Zhu Yingtai” (梁山伯与祝 英台） to publicize China's long-standing traditional culture and to show the new atmosphere of literature and art after the founding of New China. He wrote on the invitation: "Please enjoy a color opera film, Romeo and Juliet in China."[5]This ingenious introduction has made this color opera film made in China highly appreciated in the international community. It is true that Chinese Yue Opera is quite different from English Opera, and "Liang Shanbo and Zhu Yingtai" differs "Romeo and Juliet" in many aspects, but with the help of such a comparison, Premier Zhou ingeniously introduced Chinese literature and culture to foreign audience and showed the "cultural soft power" of New China in the international community.

There are numerous examples of bridging the gap between Chinese and western literature by comparative methods. Proust's A la recherche du temps perdu was named as "Dream of Red Mansions in France", while Chinese contemporary poetess Yu Xiuhua（余秀华）was regarded as "Emily Dickinson in China", and Mo Yan is regarded as "William Faulkner in China". In previous literary comparisons, literature with transnational, cross-linguistic and cross-civilized characteristics is often comparable only when it has homology or homogeneity. However, since the establishment of the variation theory of the Chinese School of comparative literature, a broader bridge has been built to realize the comparative study of Chinese and Western literature by comparing and exploring the value of literary heterogeneity and variability in literary communication. Teachers of English and American literature in colleges and universities can adopt the modes of "influence study", "parallel study", "variation study" and "general literature" in comparative literature to guide students to think about the homogeneity, heterogeneity, variability and complementarity of English and American literature and Chinese literature so as to cultivate students' global awareness.

\section{Improving Mutual Understanding by Intercultural Elucidation}

From the beginning of the 20th century, many western contemporary literary theories, including formalism, the New Criticism, phenomenology, hermeneutics, reception aesthetics, structuralism, deconstruction, psychoanalysis, post-colonialism and western Marxism, have been translated into Chinese and exerted great influence on Chinese literary theories. $\mathrm{Li} \mathrm{Bai}$ is generalized as "romanticism", $\mathrm{Tu} \mathrm{Fu}$ "Realism", Mo Yan "Magical Realism". For a long period of time, those who adhered to the traditional Chinese literary discourses and speech style had been either regarded as narrow cultural nationalists or regarded as cultural conservatives. In 1995, Cao Shunqing discovered that China was losing its traditional discoursing ways and paroles. He pointed out that "Chinese modern and contemporary literary theory basically borrows a set of discourse from the West, and has long been in the 'aphasia' state of expression, communication and interpretation of literary theory."[6] Generally speaking, the Chinese literary theory featured with intuitive experience-based "sense of knowledge" was forced to be shifted to logical analysis based on "knowledge and ideal form". Later, he wrote several papers to advocate academia to cure the "aphasia" of Chinese traditional literary theories and aroused many discussions. After more than a decade's endeavor, this situation became better in China.

In fact, it has been proved by history that the communication between Chinese and Western literary theory cannot be a one-way elucidation of "from the west to China" or "from China to the west". Only by realizing the two-way intercultural elucidation in a multicultural context can we truly achieve a true mutual understanding about both civilizations. Therefore, based on this conception, the English and American literature courses for English majors in China should try a two-way intercultural elucidation: to discuss overseas Sinology with Western literary theories and to discuss English and American Literature with Chinese literary theories, especially Chinese classical literary theories.

Intercultural elucidation is an effective way to promote the integration of Chinese and Western literature, no matter it is used to prove the utility of Western literary 
theories on Chinese literature or the utility of Chinese traditional literary theories on English and American literature. Against a background that deconstruction which advocates diversity prevails, Chinese traditional literary theory, which is an important part of Chinese excellent culture, can take the chance to show its unique charm. Mikhail Bakhtin once illustrated his understanding about dialogues. He said that "We should know that, in ideological field of vision of any times and of any social group, there exists not one truth but several contradictory truths; not one pathway but several separate ideological pathways."[7] Dialogues are bidirectional not unidirectional. Intercultural elucidation is a useful method to improve mutual understanding between China and Anglophone world, because in the process of intercultural elucidation, on the one hand, students can learn to understand the universal emotions and artistic skills contained in both Western literature and Chinese literature, and on the other hand, students can also feel the special charm of English and American literature through their own thinking mode and literary discourses.

\section{Analyzing the Lateral Dynamic for Literary Development}

At present, the English and American literature courses in China still focuses on some important English and American writers, works and genres in various periods with chronological clues in the framework of national literature. But, in fact, British and American literature does not develop completely independently in vacuum. As one of the world's four ancient civilizations and a modern power, China certainly and naturally has some impacts on the British and the American in terms of literature. For example, English sonnets have always been considered to be disseminated from Sicily, Italy. In the thirteenth century, Italy was not as prosperous as the Near East in culture, and it received influences from Eastern Roman and Arab. However, no sonnets have been discovered in Greek and Arabic. To one's surprise, it is found in China which is east to Arab. Li Bai's "Drinking Alone in the Moonlight”(月下独酌) and “Laughing at the Confucian Scholars in Lu”(嘲鲁儒) possess typically early Italian sonnet features. Therefore, it is very probable that sonnets originated in China, spread to Italy via Arab, and then to the United Kingdom.

In the introduction to the History of Development and Comparison of World Literature, Professor Cao Shunqing pointed out "If 'conversion' or 'inheritance and innovation' is an important law for the vertical development of literary history, then the 'transplantation' and 'variation' of various ethnic literatures is an important law for the horizontal development of literature." [8] As Professor Cao said, literature development is mainly pushed by two basic forces: vertical and horizontal. The traditional English and American literature textbooks obviously only focus on the vertical development of literature and ignore the lateral impact of it. In fact, the jumps, mutations, and fractures in the development of literature are closely related to the horizontal development of literature. Only by comprehensively understanding the interweaving literary driving force can students truly understand the laws of world literature development. A more affirmatory example is that Pound absorbed the elements of Chinese classical poetry and greatly influenced American poetry revolution. American imagist poems demonstrated obvious horizontal impacts from Chinese ancient poems.

In the past, the teaching of English and American literature lacked the perspective of the horizontal dynamic for literary development. Textbook editors were not fully aware of China's important influence on the development of English and American literature. By analyzing the lateral dynamic for literary development, teachers can make up for present textbooks' deficiency. On the one hand, students can fully understand the rule of literature development; on the other hand, their cultural confidence of Chinese literature is enhanced.

\section{Conclusions}

On March 28, 2015, China's National Development and Reform Commission, the Ministry of Foreign Affairs, and the Ministry of Commerce jointly issued a decree "Visions and Actions for Promoting the Construction of the Silk Road Economic Belt and the 21st Century Maritime Silk Road"[9]. The Belt and Road construction visions and actions decree places special emphasis on strengthening dialogues among different civilizations, seeking common ground while reserving differences, and achieving peaceful coexistence and common prosperity. As important talents for Chinese and Western cultural and literary exchanges, English majors in China should not only fully absorb and understand Western culture and literature, but also actively promote Chinese literature to join "World Literature" and promote the internationalization and canonization of Chinese literature. On April 14th, 2017, Guangming Daily（光明日报） published an article entitled "President of Beijing Foreign Studies University: Educate Foreign Language Talents for 'China'”. It introduced president of Beijing Foreign Languages University, Peng Long (彭龙), and his reconsiderations on "Promoting Chinese Culture to the World" and "Foreign Language Teaching". He said that "Chinese culture's going out needs both foreign language education and students' full cultural confidence. Cultural confidence stems from cultural self-awareness, while cultural self-awareness lies in the recognition of the national culture."[10] In one word, in English and American literature courses, English majors in China 
should not only enlarge their horizon to know some famous writers and writings in the Anglophone world but also consciously inherit, disseminate and promote Chinese literature. In order to realize the Chinese dream of grand rejuvenation, English and American Literature should combine teaching of English and American Literature with cultivation of students' confidence of Chinese literature, so a comparative analysis between English and American literature and Chinese literature should be employed in Chinese higher education institutions. A comparative perspective in foreign literature teaching is useful for anyone who endeavors to strike a balance between learning from foreign literature and maintaining its own cultural identity.

\section{Acknowledgements}

This essay is an achievement of the project "Exploration of English Teaching Modes in the Background of Chinese Culture Going out” (JY2018060) and "Ideological and Political Education in English and American Literature Courses” (BKJX2019073) supported by Chengdu University of Information Technology. I am grateful for the fund to enable me to make research on this project.

\section{REFERENCES}

[1] Tianzheng Xie, Finding a place for the foundling: the literary position of translated literature [J]. Shanghai Literary Theory, 1989(3).

[2] Tianzheng Xie, The New Horizon of Translation Study [M]. Fuzhou: Fujian Education Press, 2015.

[3] Qing Yang \& Geng Yanrong, Translator’s Creativity-on the status of the translated literature and identity of a translator [J]. Journal of Yanshan University, 2003 (8): 43-46.

[4] Jie Lu, Literature Ethics $\cdot$ Literature Translation · World Literature: An Interview with Professor Thomas Oliver Beebee [J]. Fudan Forum on Foreign Languages and Literature, 2017(2):68-73.

[5] Hongfeng Li. To commemorate Zhou Enlai, a Great Public Servant [EB/OL].(2015-03-05).http://theory.people.com.c n/n/2015/0305/c83855-26641603.html

[6] Shunqing Cao. Aphasia in Literary Theory and Cultural Morbidity [J]. Literary and Artistic Contention.1996 (2): 50-59.

[7] Bakhtin, Mikhail. Formalist Approach of Literature and Art (Vol. 2 of collected Works of Bakhtin). Shijiazhuang: Hebei Education Press, 1998.

[8] Shunqing Cao. History of Development and Comparison of World Literature [M].Beijing: Beijing Normal
University Press, 2006: 18.

[9] Visions and Actions for Promoting the Construction of the Silk Road Economic Belt and the 21st Century Maritime Silk Road [EB/OL]. (2015-06-27).http://news.xinhuanet.c om/finance/2015-03/28/c_1114793986.htm

[10] Xiaoxia Wang. President of Beijing Foreign Studies University: Educate Foreign Language Talents for "China" [N]. Guangming Daily. [EB/OL]. (2017-04-14). http://edu.china.com.cn/2017-04/14/content_40619457.ht m. 